\title{
Az újonnan kialakított ellenállóképesség-fokozó program hatása a szülők és tanárok által észlelt ellenállás-támogató környezetre a hongkongi Egészségfejlesztő Iskolákban
}

\author{
The impact of a newly designed resilience-enhancing programme on \\ parent- and teacher-perceived resilience environment among Health \\ Promoting Schools in Hong Kong
}

Ismertető: $\quad$ Maczali Katalin $₫$

Állami Egészségügyi Ellátó Központ

Szerzők: Wong M C S, Sun J, Lee A, Stewart D, Cheng F F K, Kan W, Ho M.

Megjelenés: Journal Epidemiol Community Health 2009;63:209-214. doi:10.1136/jech.2008.074260

Beküldve: 2017.09.12.

doi: $10.24365 /$ ef.v58i3.184

Kulcsszavak: ellenálló-képesség; iskolai egészségfejlesztés

\section{ÖSSZEFOGLALÁS}

A kínai fiatalok körében a rossz mentális egészség komoly problémát jelent a városi és vidéki területeken egyaránt. Az érzelmi és társas egészség az iskolai egészségfejlesztés egyik központi témája.

A mentális egészségfejlesztés területén megjelent friss kutatások szerint a pszicho-szociális jólét az ellenálló-képességben gyökerezik. Ez az egyének, az iskolák, a családok és közösségek azon képességére utal, amellyel sikeresen megbirkózhatnak a mindennapi kihívásokkal, beleértve a felgyülemlő stresszt és más szignifikáns kockázatokat.

A kutatás célja volt, hogy kielemezze a kialakított és bevezetett ellenállóképesség-fokozó programnak a hatásosságát.

Az Egészségfejlesztő Iskolák (EI) erős alapokat nyújtanak a diákok általános egészségének fejlődéséhez, beleértve a pszichológiai jólét fejlődését is, amely az ellenálló-képességből gyökerezik. A jelenlegi kutatás célja, hogy megvizsgálja az ellenállóképesség-fokozó program hatásosságát, amelyet az EI koncepciója lapján dolgozta ki a kínai populációra.
A hongkongi társadalmilag hátrányosabb régió iskoláiból választottak mintát El és nem El iskolák közül, akik kontrollcsoportként szolgáltak. A résztvevők: a tanárok, illetve a 8, 10, és 12 éves diákok szülei voltak, összesen 4918 szülő és 602 tanár szerepelt a kutatásban.

Az ellenállóképesség-fokozó program 4 hónapig tartott 2005 októberétól 2006 januárjáig, az adatokat pedig a program előtt, majd a program után 8 hónappal gyűjtötték be.

A program két részből állt: egy két órás független beszélgetésből minden egyes tanárral, akik az egészség népszerűsítésért felelősek, valamint szülőkből és tanárokból álló interaktív munkacsoportokból, amelyeket tapasztalt szociális munkások vezettek.

Ez a kínai populációra szabott kutatás, szignifikáns hatást mutatott az iskolai ellenálló-képesség erősítésére az El középiskolás tanárok körében. Nehéz meghatározni azonban, hogy a pozitív hatások az ellenállóképesség-fokozó programok hatása vagy csak a már korábban beépített El program következményei. 


\section{KULCSÜZENET A SZAKEMBEREK SZÁMÁRA}

A program célja, hogy pozitívabb felnőtt és kortárs szociális hálót, erősebb összetartozás érzést, valamint támogató fizikai és társadalmi környezetet fejlesszen ki, illetve a diákok körében erősödjenek az ellenálló-képességgel kapcsolatos viselkedésformák, mint az önbizalom, empátia, segítségkérés, kommunikáció és együttmúködés. Ezek a programok hatékonyabban bevonják a szülőket, mind a többi szülővel való kapcsolattartásban, mind a család és iskola közötti együttműködésben, az iskolai tevékenységekben való részvételben. Emellett Tanár-Szülő Egyesületek is egyre elterjedtebbek több kínai középiskolában. 